\title{
Regional Analysis of Implementation of the National Rural Development Programme 2007-2013
}

\author{
Camelia TOMA*, Camelia GAVRILESCU, Crina TURTOI \\ Institute of Agricultural Economics, Romanian Academy \\ ${ }^{*}$ Corresponding author, e-mail: cameliatoma2004@yahoo.fr \\ BulletinUASVM Horticulture 74(1) / 2017 \\ Print ISSN 1843-5254, Electronic ISSN 1843-5394 \\ DOI:10.15835/buasvmcn-hort:12261
}

\begin{abstract}
Rural areas, representative for Romania, have substantial development resources, but unevenly distributed in terms of demography, landforms, soil, climate and vegetation. These disparities are reflected in the socio-economic development of the respective areas and the quality of life of their rural population. The study examines regional disparities in the implementation of the RDP 2007-2013 based on information and public data of the monitoring reports and, as well, based on the previous studies of other research teams. The data used were taken from the national statistics, as well from national publications, on which we made calculations and own interpretations. The study analyzed the degree of reaching the objectives set in terms of public expenditure by the end of 2015, grouped by axes, measures, development regions and counties. The research results have revealed an in homogeneity between realized and planned public spending, both at axes level and measures one, while significant differences in regional and county level were as well observed. Some causes of lower absorption of certain measures were generally at national level, beneficiaries encountering difficulties due to lack of own resources for co-financing, while others were due to long periods of implementation specific to particular investment domains. For other measures, the multiannual or specific nature of certain geographical and environmental areas, or the amount of the granted grants, favoured exceeding of the allocated budget expenditure or determined a high degree of absorption.
\end{abstract}

Keywords: axes, counties, development regions, European funds, measures

\section{INTRODUCTION}

Rural areas, representative of Romania, have substantial development resources highly diversified distributed in terms of relief, soil, climate, hydrology and vegetation, but also as demographic dispersal. On the area of the rural space by $207520 \mathrm{~km} 2$ the rural population is not evenly distributed. Thus, the rural population has a high proportion in certain regions (South Muntenia - 58.6\%, North East - 56.8\% and SouthWest Oltenia - 51.9\%). The highest density, excepting Bucharest-Ilfov Region, was recorded in Northeast (63.24 inhabitants / km2), while in West region rural areas are less populated (26.51 inhabitants / km2). These disparities are reflected in the socio-economic development of these areas and the quality of life of rural population.

The study examines regional disparities in the implementation of the NPRD 2007-2013 based on information and data coming from the public dissemination of the monitoring reports, and from previous studies disseminated by other research teams (Goşa V et al.,2014).

\section{MATERIALS AND METHODS}

The methods used were analysis, synthesis, comparison method, deduction and induction. The data used were taken from the national statistics, as well from national publications, on which we made calculations and own interpretations. The 
study examined the disparities related to the degree of accomplishment of the objectives set-up and the share of the effective funding by the end of 2015, grouped after axes, measures, development regions and counties.

\section{RESULTS AND DISCUSSIONS}

Under the National Strategic Plan, the National Rural Development Programme 2007-2013, took into account three key issues, namely: "(i) facilitate the transformation and modernization of the dual structure of agriculture and forestry, as well as related processing industries, to make them more competitive and to contribute to economic growth and income convergence in rural areas (where possible), while ensuring environmental protection and living conditions in these areas; (ii) maintaining and improving environmental quality in rural areas of Romania, by promoting the sustainable management of both agricultural areas and on the forest areas; (iii) managing and facilitating the transition of labor from agriculture to other sectors to ensure adequate living standards from socially and economically point of view."

Between March 3, 2008 and July 31, 2014 under Axes I, III, IV there were submitted to PARDF ${ }^{1}$ / FARI ${ }^{2}$ over 150 thousand projects through were requested 18.6 billion Euro.

Through a rigorous selection and due to outflows from the system for various reasons, there were contracted and runs activities in the frame of 82500 projects, respectively $55 \%$ of all submitted projects, amounting 5.5 billion Euro, which covered $30 \%$ of the required amount requested for the respective period (Table 1 ).

Axis II was entrusted for monitoring and payment to APIA. The objectives were to maintain biodiversity, soil quality, avoidance of isolation and abandonment of agricultural land. The financial support of 3.1 billion Euros, related to agri-environment measures and LFA was compensatory and was based on "payment applications", by fulfilling specific conditions and eligibility criteria for applying direct payment schemes and complementary national direct payments in the vegetable sector.

\footnotetext{
${ }^{1}$ The Payment Agency for Rural Development and Fishing (PARDF)

${ }^{2}$ Funding Agency for Rural Investments (FARI)

${ }^{3}$ Agency for Payments and Intervention in Agriculture
}

In order to update the legal framework properly for the implementation of the National Program for Rural Development 2007-2013 and to accelerate the absorption of the deployed funds, co-financed by the European Agricultural Fund for Rural Development (EAFRD), in 2015 measures were taken for improving implementation of the projects and, as well, prevention of disengagement of the funds allocated to Romania by the NRDP 2007-2013 (Fig. 1).

Thus, the level of completed public spending relative to the budget programmed for 2007-2013 with reference to NRDP axes was: $85 \%$ for Axis 1, $83 \%$ for Axis 3 and $91 \%$ for Axis 4 from total allocated budget.

Axis 2, entrusted for monitoring and payment to APIA, had a level of expenditure, in the form of direct payments of $96 \%$. Expenditure of Axis 2 had the highest absorption, mainly due to the multiannual nature of the measures (agrienvironment, LFA) and the introduction during the implementation of the NRDP of new packages (measure 214), new measures (215) or increase compensation payments (measure 211 and 212).

As well, the expenditures related to Axis 4 have an absorption percentage by over $90 \%$, registering the highest increase compared to the previous year.

Axes 1 and 3 have a level of financial absorption by over $80 \%$, lower as compared with the other axes, the main cause being a lack of own resources of the beneficiaries and the difficulties faced to get loans to ensure co-financing required for project implementation, in the frame of the overall financial crisis, and, as well, financing under axis 3 of the forestry and rural infrastructure integrated projects, which requires a long period of implementation.

In 2015, in order to accelerate the absorption of funds, improvements were done both in methodology and the staff involved in monitoring and paymentactivities, so thatfinancial implementation rate has made significant progress:

Axis 1 - funding rate increased from 63\% to $85 \%$ (relative to axis budget);

Axis 2 - funding rate decreased from 101\% to 96\% (due to the supplementation of the budget the share of payments in total budget decreased, the emergence of new partial payment, opening the new measures of NRDP 2014-2020); 
Tab. 1. The level of public financial allocation compared to the amount needed

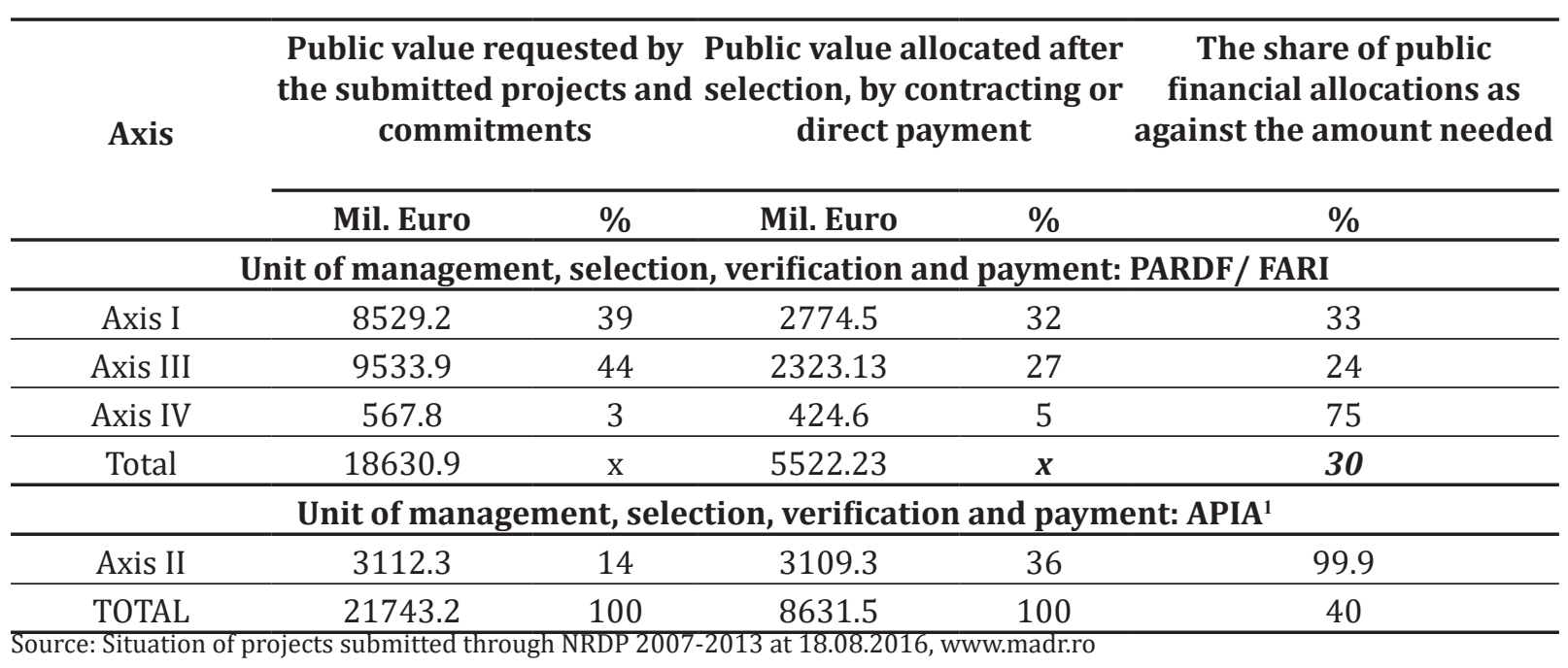

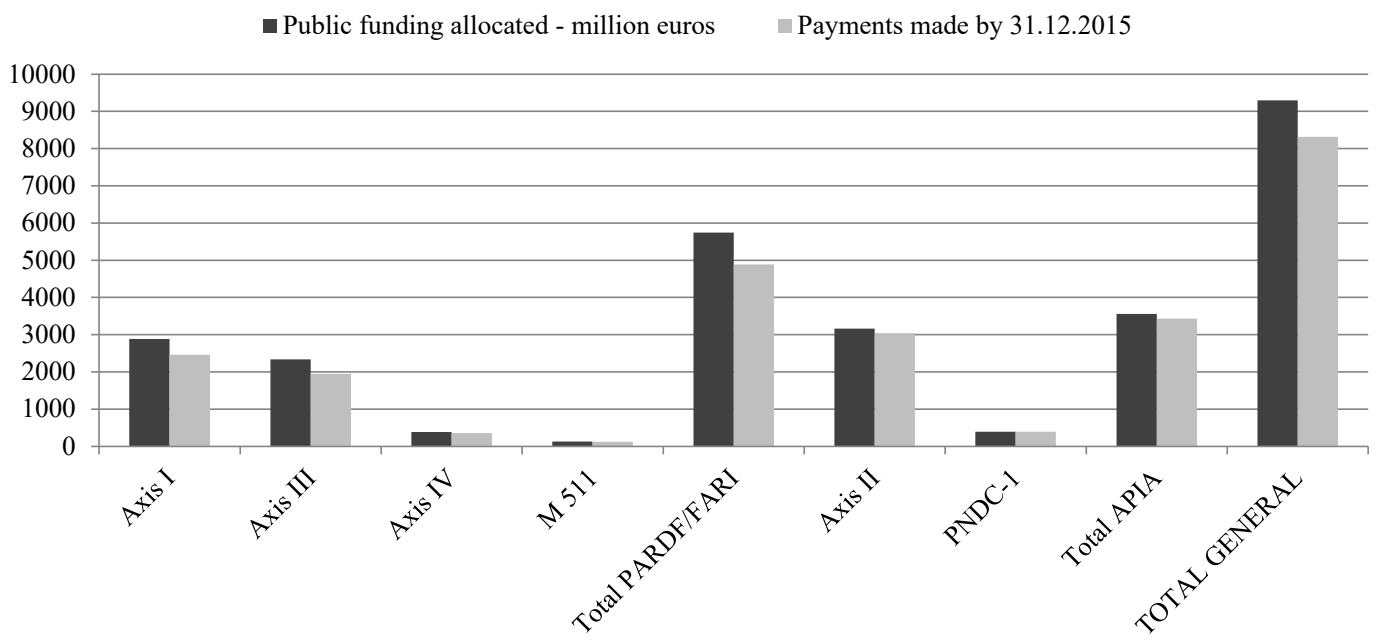

Fig. 1. Amount of scheduled funds (allocated) and public spending achieved (payments) through NRDP 2007-2013 up to 31.12.2015, structured on axes and Units of management, selection, verification and payment

Axis 3 - funding rate increased from $73 \%$ to $83 \%$ (relative to axis budget);

Axis 4 - funding rate increased from $37 \%$ to $91 \%$ (relative to axis budget).

Analysis of financial implementation/ achievement by objectives of the NRDP 2007-2013 Axes, at the end of 2015, is even more suggestive (Tab. 2).

Under NRDP 2007-2013 there were established 11 objectives, three objectives by each of Axes I, III and IV and two objectives for Axis II, comprising a variable number of specific measures. Out of total Axes, Objectives 2, 4, 5 and 8 are amounting nearly $80 \%$ of the total allocated budgetary value, with funding rates by over $90 \%$.

Analysis of the regional distribution of NRDP 2007-2013 implementation reveal significant disparities in terms of number and value of projects carried out through the 3 Axes monitored by PARDF / FARI (Fig.2).

North-West region stands with almost 20000 projects, followed by North-East and South-East regions. The other regions are running below 10 thousand projects each. In terms of contracted amounts, North-West is on first place with over 1 billion Euros, followed by the North-East, South- 
Tab. 2. The degree of financial implementation/achievement of NRDP 2007-2013, structured on the objectives of program axes

\begin{tabular}{|c|c|c|c|c|c|}
\hline Objectives & $\begin{array}{c}\text { Public } \\
\text { financial } \\
\text { allocation by } \\
\text { objective, mil. } \\
\text { Euro } \\
\end{array}$ & $\begin{array}{c}\text { Share of } \\
\text { objective in } \\
\text { total public } \\
\text { funding/axis } \\
-\% \text { - }\end{array}$ & $\begin{array}{l}\text { Payments made } \\
\text { from public } \\
\text { allocation by } \\
\text { objective, mil. } \\
\text { euro } \\
\end{array}$ & $\begin{array}{c}\text { Share of } \\
\text { payments on } \\
\text { objective in total } \\
\text { public funding/ } \\
\text { axis -\%- }\end{array}$ & $\begin{array}{l}\text { The funding } \\
\text { rate of the } \\
\text { objective as of } \\
31.12 .2015-\%- \\
\end{array}$ \\
\hline $\begin{array}{c}\text { Objective 1. } \\
\text { Improving managerial skills of farmers and staff in } \\
\text { agriculture, agri-food and forestry industry } \\
\text { (M 111, M 143) }\end{array}$ & 91.6 & 3 & 24.4 & 1 & 27 \\
\hline $\begin{array}{l}\text { Objective } 2 \text {. } \\
\text { Improving the competitiveness of commercial and } \\
\text { subsistence farms and agriculture and forestry } \\
\text { infrastructure. } \\
\text { (M 112, M 141, M 121, M 125) }\end{array}$ & 2048.9 & 71 & 1874.2 & 76 & 91 \\
\hline $\begin{array}{l}\text { Objective } 3 . \\
\begin{array}{c}\text { Restructuring and upgrade the processing and } \\
\text { marketing sectors of agricultural and forestry } \\
\text { products (M 122, M 123, M 142) }\end{array}\end{array}$ & 744.7 & 26 & 560.2 & 23 & 75 \\
\hline Axis I & 2885.2 & 100 & 2458.8 & 100 & 85 \\
\hline $\begin{array}{c}\text { Objective } 4 . \\
\text { Sustainable use of agricultural land in disadvantaged } \\
\text { areas } \\
\text { (M 211, M 212) }\end{array}$ & 1205.2 & 38 & 1202.6 & 40 & 99.8 \\
\hline $\begin{array}{c}\text { Objective 5. } \\
\text { Conservation and improvement of natural resources } \\
\text { and habitats } \\
(\mathrm{M} \mathrm{214,} \mathrm{M} \mathrm{215)}\end{array}$ & 1958.8 & 62 & 1835.4 & 60 & 94 \\
\hline $\begin{array}{l}\text { Objective } 6 . \\
\text { Promoting the sustainable management of forests } \\
\text { (M 221) }\end{array}$ & 3.2 & 0.1 & 0.5 & 0.02 & 16 \\
\hline Axis II & 3163.2 & 100 & 3038.5 & 100 & 96 \\
\hline $\begin{array}{c}\text { Objective } 7 . \\
\text { Maintaining and developing economic activities } \\
\text { (micro and rural tourism) to increase the number of } \\
\text { jobs (M 312, M 313) }\end{array}$ & 649.9 & 28 & 411.1 & 21 & 63 \\
\hline $\begin{array}{c}\text { Objective 8. } \\
\text { Increase the attractiveness of rural areas by } \\
\text { renovating villages and bolstering tourism and } \\
\text { leisure } \\
\text { (M 322, M 313) }\end{array}$ & 1687.9 & 72 & 1539.8 & 79 & 91 \\
\hline Axis III & 2337.8 & 100 & 1950.9 & 100 & 83 \\
\hline $\begin{array}{l}\text { Objective } 9 . \\
\text { Participation of members of rural communities in the } \\
\text { rural development process and encourage innovative } \\
\text { activities } \\
\text { (M 411, M 412, M 413) }\end{array}$ & 315.6 & 82 & 298.6 & 84 & 95 \\
\hline $\begin{array}{c}\text { Objective 10. } \\
\text { Encouraging local actors to work together with } \\
\text { representatives of other communities from inside or } \\
\text { outside the country (M 421) }\end{array}$ & 3.2 & 1 & 1.1 & 0.3 & 34 \\
\hline $\begin{array}{l}\text { Objective 11. } \\
\text { Fostering initiation of partnerships, preparing and } \\
\text { ensuring the implementation of rural development } \\
\text { strategies } \\
\text { ( M 431-1, M 431-2) } \\
\end{array}$ & 67.3 & 17 & 53.7 & 15 & 80 \\
\hline Axis IV & 386.1 & 100 & 353.4 & 100 & 92 \\
\hline Total AXES & 8772.3 & 94 & 7801.6 & 94 & 89 \\
\hline NRDP technical assistance (M511) & 131.6 & 1 & 125.3 & 2 & 95 \\
\hline $\begin{array}{l}\text { Complementary National Direct Payments Scheme } \\
\text { (M 611) }\end{array}$ & 392.5 & 4 & 391.2 & 5 & 99.7 \\
\hline TOTAL NRDP 2007-2013 & 9296.4 & 100 & 8318.0 & 100 & 90 \\
\hline
\end{tabular}




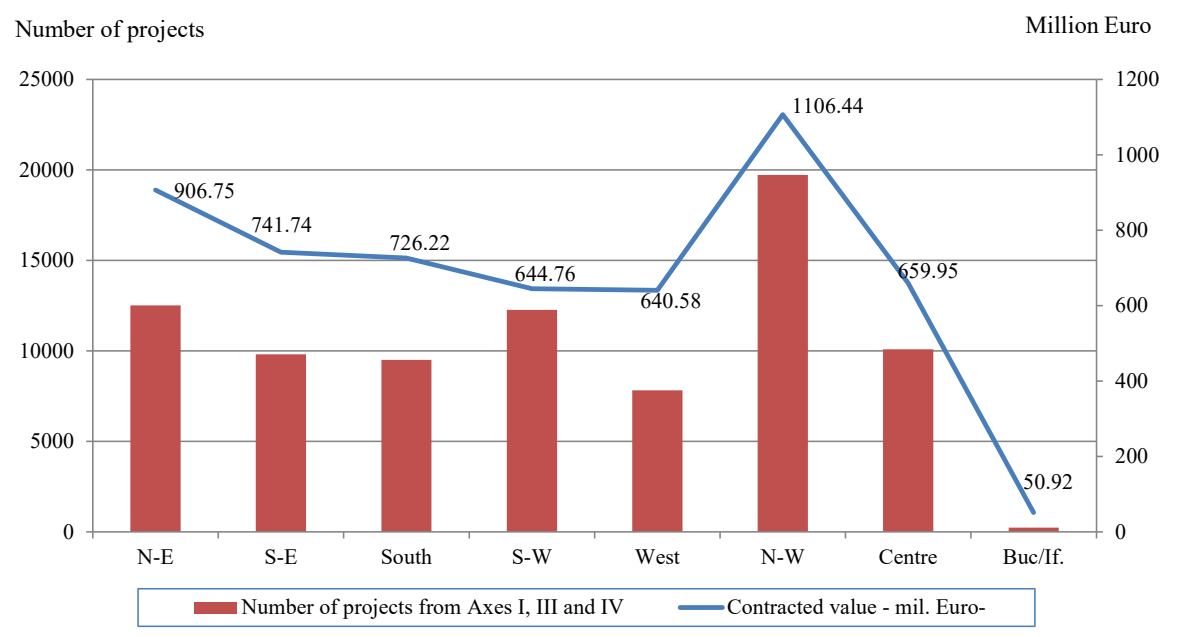

Fig. 2. The number of projects and the contracted value through PARDF / FARI from NRDP 2007-2013, remained in the system as at 31.12.2015

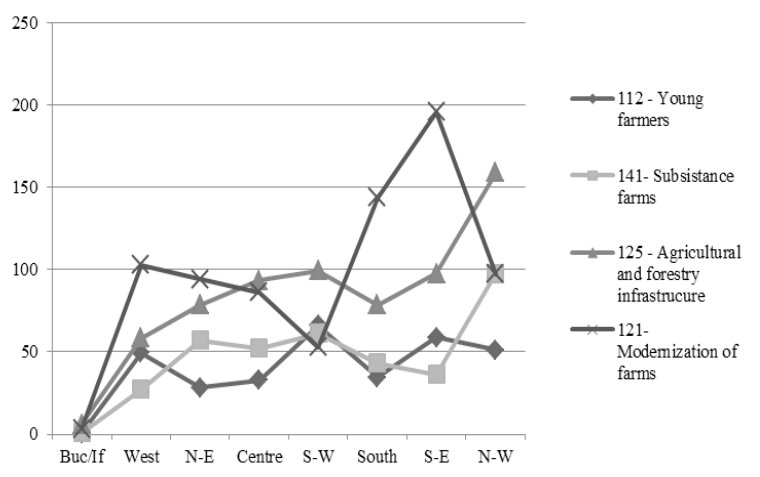

Fig. 3. Regional distribution of the contracted amounts (mil. Euro) by Measures of Objective 2

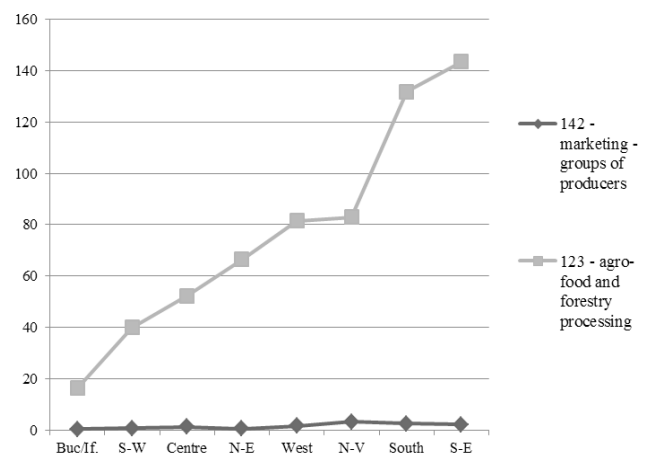

Fig. 4. Regional distribution of the contracted amounts (mil. Euro) by Measures of Objective 3
East and South regions, with over 700 million Euros each.

Objective 2: Improvement of the competitiveness of commercial and subsistence farms and of the agricultural and forestry infrastructure, (Tab. 2), includes the Measures "installing young farmers", "support for semi-subsistence farms", "investment to modernize farms" and "investment in agricultural and forestry infrastructure". Analysis of the regional distribution of contracted amounts highlights South-East and South regions for Measure „investment to modernize farms”, NorthWest for Measures "investment in agricultural and forestry infrastructure" and Measure "support for semi-subsistence farms" and South-West for Measure "installing young farmers" (Fig. 3).

Objective 3: Restructuring and modernization of the processing and marketing of agricultural and forestry products includes the related measures: "improving the economic value of forests", "processing of agri-food and forestry products" and "establishing producer groups (marketing of agricultural products)". The analysis of the regional distribution of the contracted amounts highlights South and South-East regions for measure related to processing of agri-food products and NorthWest region for the measure related to setting up producer groups (Fig. 4).

Objective 7: Maintaining and Developing economic activities (micro-enterprises and rural tourism) to Increase the number of jobs has a relatively homogeneous distribution with a slight outs of the North West and South at measure to support micro-enterprises and Northwest Regions and Centre for „rural tourism” (Fig. 5). 


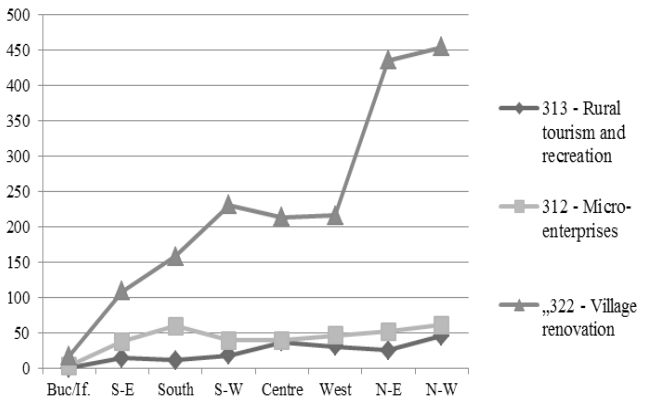

Fig. 5. Regional distribution of the contracted amounts (mil. Euro) by Measures of Objectives 7 and 8

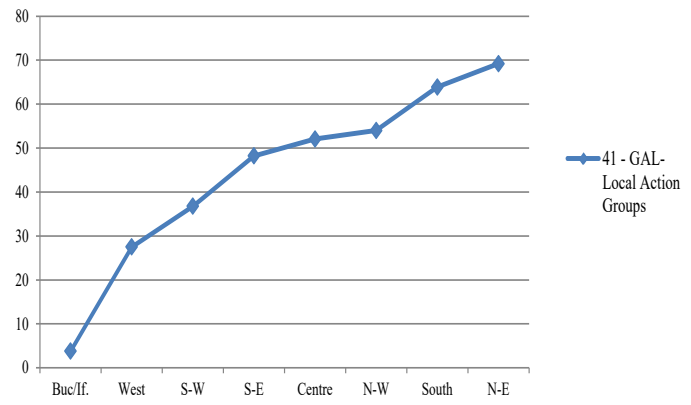

Fig. 6. Regional distribution of the contracted amounts (mil. Euro) by Measures of Objective 9

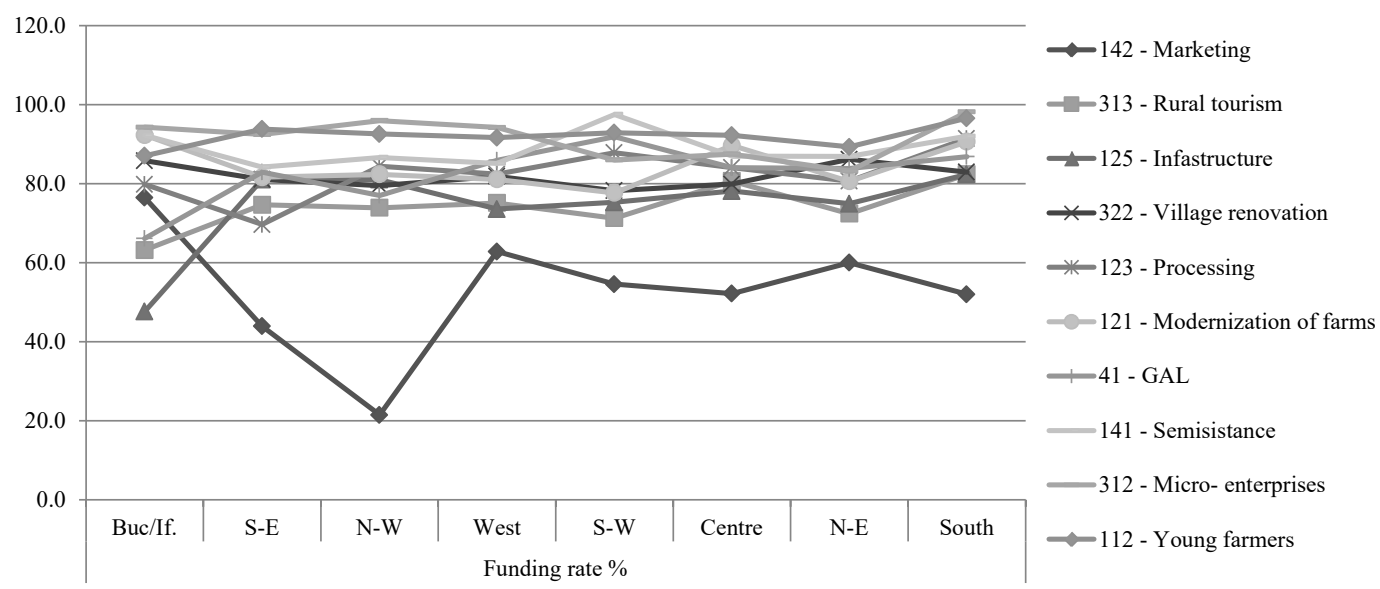

Fig. 7. The financial execution rate of measures from Axes I, III and IV of the PNDR 2007-2013 at 31.12.2015, grouped by development regions

Objective 8: Increased attractiveness of rural areas by renovating villages and bolstering tourism and leisure is well established in the North-West and North-East, with higher amounts contracted as compared with the rest of the regions (Fig. 5).

Objective 9: Participation of the members of rural communities in the rural development process and encouraging innovative activities include support activities by local action groups (GAL) to implement complementary measures to increase competitiveness in agriculture and forestry sectors, improving the environment and the countryside and, as well, the quality of life and diversification of rural economy. It can be noted that North-East, South, North-West and Central regions contracted amounts exceeding 50 million Euros each (Fig. 6).

As it was stated previously, the financial implementation rate was accelerated in 2015, the vast majority of measures achieving a high absorption in all development regions. There is a lag and a slow uptake of the measure providing support formation of producer groups with the aim of better marketing of agricultural products. If for other measures, North-West and South-East are the leading in the funding rate, for this measure the funding rate is only $20-40 \%$. Bucharest/Ilfov region is the only one where the funding rate is approaching $80 \%$. The Influence of proximity to the capital of the country and the great demand has encouraged farmers' association (especially the ones specialized on vegetables and fruits) for a better supply of the large stores (Fig. 7).

A more detailed analysis of the level of funding rate by regions and measures until 31.12.2015 highlights the following (Tab. 3):

South Region recorded an average rate of absorption of funds of $88.6 \%$. This results out of a funding rate of $90 \%$ to measures concerning young farmers, the creation of micro-enterprises 
Tab. 3. Regional distribution in the average rate of funding measures form NRDP 2007-2013 at 31.12.2015

\begin{tabular}{|c|c|c|c|c|c|c|c|c|}
\hline $\begin{array}{l}\text { Funding } \\
\text { rate } \% \\
\end{array}$ & Buc./ If. & S-E & $\mathrm{N}-\mathrm{V}$ & Vest & $S-V$ & Centre & N-E & South \\
\hline $\begin{array}{l}\text { Average } \\
\text { by region }\end{array}$ & $78,5 \%$ & $80,6 \%$ & $82 \%$ & $82,6 \%$ & $82,7 \%$ & $83,2 \%$ & $83,6 \%$ & $88,6 \%$ \\
\hline $20-30$ & $\mathrm{x}$ & $\mathrm{x}$ & Marketing & $\mathrm{x}$ & $\mathrm{x}$ & $\mathrm{x}$ & $\mathrm{x}$ & $\mathrm{x}$ \\
\hline $41-49$ & Infrastructure & Marketing & & $\mathrm{x}$ & $\mathrm{x}$ & $\mathrm{x}$ & $\mathrm{x}$ & $\mathrm{x}$ \\
\hline $50-59$ & $\mathrm{x}$ & $\mathrm{x}$ & $\mathrm{x}$ & $\mathrm{x}$ & Marketing & Marketing & Marketing & Marketing \\
\hline $60-69$ & $\begin{array}{c}\text { Rural tourism, } \\
\text { GAL }\end{array}$ & Processing & $\mathrm{x}$ & Marketing & $\mathrm{x}$ & $\mathrm{x}$ & $\mathrm{x}$ & $\mathrm{x}$ \\
\hline $70-79$ & $\begin{array}{l}\text { Marketing, } \\
\text { processing }\end{array}$ & Rural tourism & $\begin{array}{c}\text { Rural tourism, } \\
\text { renovation of } \\
\text { villages, GLA }\end{array}$ & $\begin{array}{l}\text { Rural tourism, } \\
\text { infrastructure }\end{array}$ & $\begin{array}{c}\text { Rural tourism, } \\
\text { infrastructure, } \\
\text { renovation } \\
\text { of villages, } \\
\text { modernization } \\
\text { of farms }\end{array}$ & $\begin{array}{c}\text { Infrastructure, } \\
\text { renovation of } \\
\text { villages }\end{array}$ & $\begin{array}{l}\text { Rural tourism, } \\
\text { infrastructure }\end{array}$ & $x$ \\
\hline $80-89$ & $\begin{array}{c}\text { Renovation of } \\
\text { villages, } \\
\text { Young farmers }\end{array}$ & $\begin{array}{l}\text { Infrastructure, } \\
\text { renovation } \\
\text { of villages, } \\
\text { modernization } \\
\text { of farms, } \\
\text { GLA, } \\
\text { semi- } \\
\text { subsistence }\end{array}$ & $\begin{array}{c}\text { Infrastructure, } \\
\text { Processing, } \\
\text { modernization } \\
\text { of farms, } \\
\text { semi- } \\
\text { subsistence }\end{array}$ & $\begin{array}{l}\text { Renovation, } \\
\text { processing, } \\
\text { modernization } \\
\text { of farms, } \\
\text { GLA, } \\
\text { semi- } \\
\text { subsistence }\end{array}$ & $\begin{array}{l}\text { Processing, } \\
\text { micro- } \\
\text { enterprises }\end{array}$ & $\begin{array}{l}\text { Rural tourism, } \\
\text { processing, } \\
\text { modernization } \\
\text { of farms, } \\
\text { GLA, } \\
\text { semi- } \\
\text { subsistence, } \\
\text { micro- } \\
\text { enterprises }\end{array}$ & $\begin{array}{l}\text { Renovation } \\
\text { of villages, } \\
\text { processing, } \\
\text { modernization } \\
\text { of farms, } \\
\text { GLA, } \\
\text { semi- } \\
\text { subsistence, } \\
\text { micro- } \\
\text { enterprises, } \\
\text { young farmers }\end{array}$ & $\begin{array}{l}\text { Rural tourism, } \\
\text { infrastructure, } \\
\text { renovation of } \\
\text { villages, GLA }\end{array}$ \\
\hline $90-99$ & $\begin{array}{l}\text { Modernization } \\
\text { of farms, } \\
\text { semi- } \\
\text { subsistence, } \\
\text { micro- } \\
\text { enterprises }\end{array}$ & $\begin{array}{c}\text { Micro- } \\
\text { enterprises, } \\
\text { Young farmers }\end{array}$ & $\begin{array}{c}\text { Micro- } \\
\text { enterprises, } \\
\text { Young farmers }\end{array}$ & $\begin{array}{l}\text { Micro- } \\
\text { enterprises, } \\
\text { Young farmers }\end{array}$ & $\begin{array}{c}\text { GLA, } \\
\text { semi- } \\
\text { subsistence, } \\
\text { Young farmers }\end{array}$ & Young farmers & 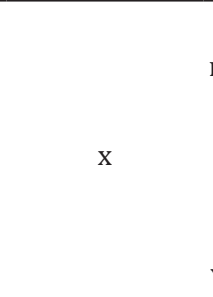 & $\begin{array}{c}\text { Processing, } \\
\text { modernization } \\
\text { of farms, } \\
\text { semi- } \\
\text { subsistence, } \\
\text { Micro- } \\
\text { enterprises, } \\
\text { Young farmers }\end{array}$ \\
\hline
\end{tabular}

in rural areas, support for semi-subsistence farms and modernization of commercial farms and the establishment and modernization of agri-food and forestry processing units and a rate in the range $80-89 \%$ for the measures relating to local action groups (GAL), village renewal, forestry and agricultural infrastructure and rural tourism.

North-East and Centre Regions, with an average funding rate of $83 \%$ achieved absorption of funds in more than $80 \%$ on most measures. Stands with a so far higher absorption rate Centre Region (over 90\%) on installation young farmers. Both regions have achieved rates ranging between 70$79 \%$ for agricultural and forestry infrastructure, renovation of villages and rural tourism.

South-West, North West and South East Regions recorded an average funding rate ranged between 80.6 - $82.7 \%$, due to proceeds obtained over $90 \%$ at the measures: installation of young farmers, creating non-agricultural microenterprises in rural areas, and receipts at a rate of $80-89 \%$ to semi-subsistence farms, modernizing farms, creating or upgrading of agri-food processing and forestry and Groups Local Action - GLA. With less weight, within range of $70-79 \%$ are payments to rural tourism, village renewal and agricultural and forest infrastructure.

Bucharest/Ilfov Region, albeit with a more special status because of the capital and surrounding areas, recorded by the end of 2015 the lowest average funding rate as compared to other regions. Poor results on the collection of funds were recorded in implementation of agricultural and forestry infrastructure measure, weighing in the 
Tab. 4. Grouping of the counties after the level of financing rate of the measures monitored by PARDF/FARI from NRDP 2007-2013, at 31.12.2015

\begin{tabular}{|c|c|}
\hline $\begin{array}{l}\text { Intervals of } \\
\text { funding rates }\end{array}$ & $\begin{array}{c}\text { Counties } \\
\text { (in ascending order) } \\
\end{array}$ \\
\hline $50-59$ & Brașov, Călărași, Brăila, Buzău, Giurgiu, Teleorman, Bihor \\
\hline $60-69$ & $\begin{array}{l}\text { Timiș, Covasna, Ialomița, Cluj, Satu Mare, Alba, Constanța, Mehedinți, Botoșani, } \\
\text { Suceava, Neamț, Dolj, Maramureș, Iași, Caraș Severin, Hunedoara, Arad, Sălaj, Sibiu }\end{array}$ \\
\hline $70-79$ & $\begin{array}{c}\text { Bacău, Tulcea, Argeș, Olt, Mureș, Harghita, Galați, Dâmbovița, Gorj, Vaslui, Vrancea, } \\
\text { Vâlcea, Bistrița Năsăud }\end{array}$ \\
\hline $80-89$ & București/Ilfov \\
\hline
\end{tabular}

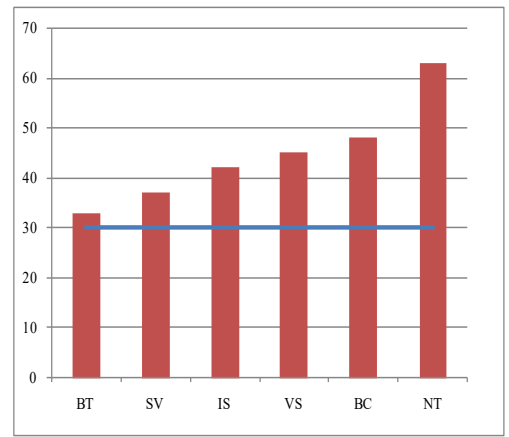

North- East

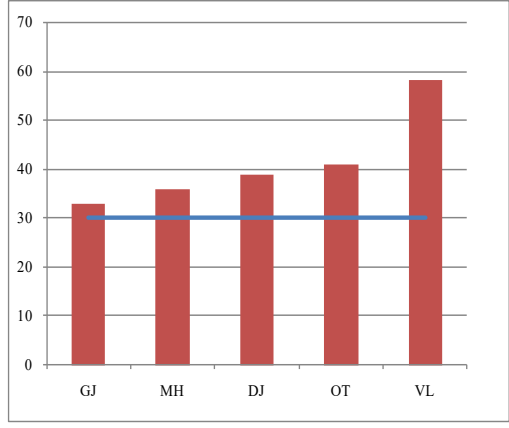

South-West

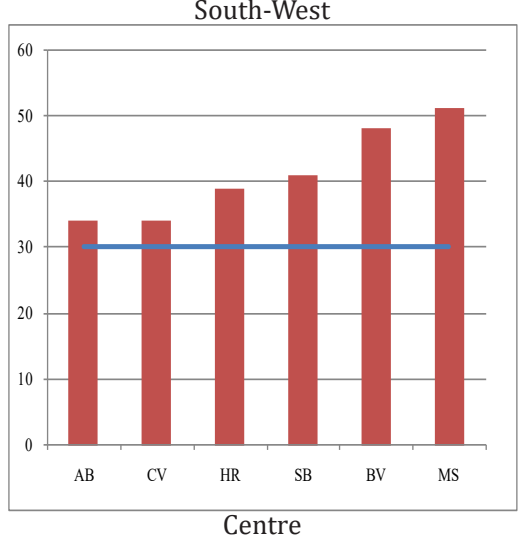

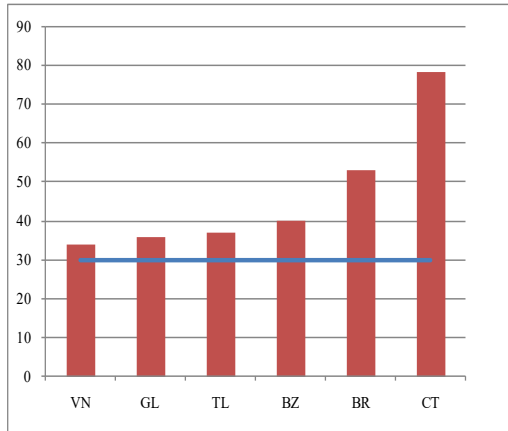

South-East

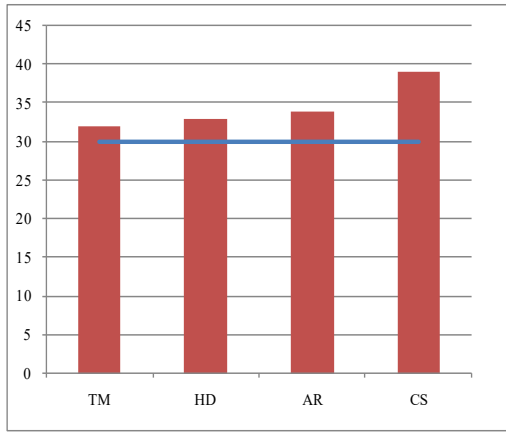

West

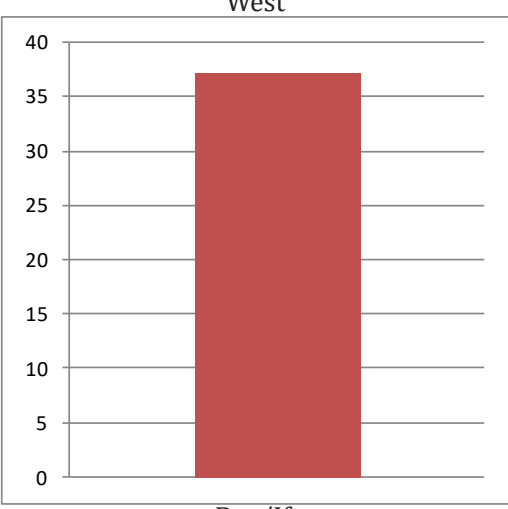

Buc/If.
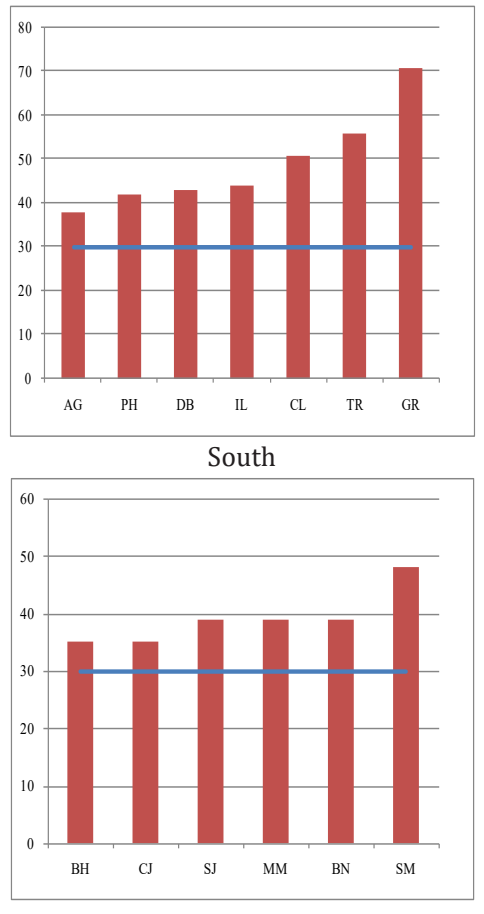

North-West

$\begin{aligned} \text { South } & =4,5 \\ \text { South-East } & =3,3 \\ \text { North-East } & =2,9 \\ \text { Centre } & =2,2 \\ \text { South-West } & =1,9 \\ \text { North-West } & =1,8 \\ \text { West } & =0,6 \\ \text { Buc/If. } & =0,2\end{aligned}$

Coefficients exceeding the mandatory minimum investment share of $30 \%$

Fig. 8. Share of the amounts invested by young farmers reported at the amount of public funding obtained from the NRDP 2007-2013, 31.12.2015, grouped by regions and counties 
range $41-49 \%$, and $60-69 \%$ for rural tourism and activities supported by Local Action Groups. With funding rates above $90 \%$ are distinguished the investments in commercial farm modernization, diversification into non agricultural activities in rural areas and supporting semi-subsistence farms.

Financing regional average rates resulted from the share of payments in the amounts allocated by the measures at county level of NRDP 2007-2013. County funding rates are relatively diversified, with lower levels or increased, ranging between $50 \%$ and $89 \%$ at the end of 2015 (Tab. 4).

As an example, it is analyzed the share of the amounts invested by young farmers in the total contracted amounts at county level (Fig. 8).

For Measure "young farmers", financial execution rate is of $98.3 \%$, with payments amounting to 298.7 million Euros from the allocation of 303.9 million Euros. The total investment volume was of 129.7 million, out of a target of 378 million Euros, resulting in a $34.3 \%$ rate of execution. According to the specifications, farmers are required to invest at least $30 \%$ of the grant received as support for installation.

Counties with the highest exceedance above the mandatory limit of $30 \%$, respectively more than half of the amounts, are Constanța (78\%), Giurgiu (71\%), Neamț (63\%), Vâlcea (58\%), Teleorman (56\%), Brăila (53\%) and Ialomița and Mureș with 51\% each.

Regional average coefficients of surpassing the threshold of $30 \%$ situates South Region on the first place, by using 4.5 times more than the amounts invested as compared with the set-up threshold of $30 \%$, considered as coefficient 1 . It follows in descending order South East Region with 3.3 coefficient and North-East Region with 2.9 coefficient. The lowest coefficients were regis- tered in the West Region (0.6 coefficient) and Bucharest/Ilfov Region (0.2 coefficient) (Fig. 8).

\section{CONCLUSIONS}

The analysis revealed heterogeneity between realized and planned public spending, both at Axes and Measures level, being noticed as well significant differences in regional and county level.

The differences between regions have quite numerous causes, many of which are objective causes. Developing regions of our country are administrative forms, artificially created, very inhomogeneous in terms of the number of component counties, areas, relief forms, rural infrastructure, soils, climate, vegetation, sightseeing attractions, rural population density, density and size of urban centers, etc.

Some known causes of lower absorption in some Measures were overall at national level, project beneficiaries encountering difficulties due to lack of own resources for co-financing, while others were due to long periods of implementation specific to the investment. At other measures, the multiannual nature or specific of certain geographical and environmental areas, or nonrefundable grants favored overcoming of the budget expenditure allocated or caused a high degree of absorption.

\section{REFERENCES}

1. 1. Goșa V et al. (2014), NRDP 2014-2020 under the influence of experience accumulate during 2007-2013, Lucrările științifice, Management Agricol, Seria I, vol. XVI (3), 93-96 p.

2. 2. Goșa V et al. (2015), NRDP 2014-2020, from needs to financial appropriations. Lucrările științifice, Management Agricol, Seria I, vol. XVII (3), 111-112 p.

3. 3. www. Madr.ro, (2016), Annual Progress Reports NRDP 2015, August.

4. 4. www. Madr.ro, (2016), Situation of the projects submitted to 18.08.2016 through NRDP 2007-2013. 